\section{P-533 術式変化による前立腺全摘術の手術成繶}

長久保クリニック1）福生病院2) 立川共済病院3)

三島 淳二 ${ }^{1}$ 堀場 優樹 ${ }^{1)}$ 長久保一朗 ${ }^{1}$ 加藤 忍 ${ }^{2}$ 荻原 秀隆 31

【目的】早期前立腺癌症例の増加に伴い、前立腺根治術も広く普 及しつつあるが、依然として難易度の高い手術であることには変 わりない。今回我々は、前立腺全摘術110例に関する手術成績を 術式の変化により比較検討した。【対象·方法】対象は、1991年8 月より1999年9月までに施行した前立腺全摘術110例であり、内訳 は年齢49オ〜76才、(平均67.2才)。術前ホルモン療法は110例中 97 例に施行した。主に深陰茎背静脈の処理に基き次の2 2群に分類し た。A群:陰茎背静脈根部を主に結紮した 48 例。B群:除茎背静脈根 部のみならず左右の深陰茎背静脈深枝を含め二重結热した62例。 それぞれについて、手術時間、出血量、輸血量、術後排尿障害等 につき比較検討した。【結果】A群B群それぞれ、平均手術時間201 分、200分と2群間に差を認めなかった。平均出血量については $1765 \mathrm{ml} 、 1352 \mathrm{ml}$ と B 群が有意に良好であった。平均輸血量におい ても 1037ml、606mlとB群が有意に良好であり、99年より施行して いる自己輸血では24例中23例 $(95.8 \%$ )が自己輸血のみで手術を終え ている。また、術後排尿障害発症についてはA群・B群とも差はな く良好な結果となった。【結論】陰茎背面静脈の処理法の改善に より著明な出血量の減少を認めた。また、手術時間には何ら差が ないことから現方法は非常に有用な術式と考えられた。

前立腺癌 前立腺全摘術

\section{P-534 前立腺澏に対する前立腺全摘術後の術後尿 失禁とPAD評価法についての検㣙}

\begin{abstract}
中村病院 泌尿器科1) 大分医科大学 泌尿器科2)
笠木康弘 ${ }^{1}$ 幸英夫 ${ }^{1 ｝ \text { 住野泰弘 }{ }^{1)} \text { 酒本 貞昭 }{ }^{1)} \text { 三股浩光 }{ }^{2\rangle}$ 松原 孝典 ${ }^{2)}$ 野村芳雄 ${ }^{2)}$

【目的】前立腺全摘術を施行した前立腺癌患者の術後尿失禁に対 しアンケート形式㧍よびPad testによる術後経過とPad評価法の有 用性について検討したので報告する。【対象と方法】1998年4月か ら1999年8月までに当施設にて前立腺癌と診断され前立腺全摘術を 施行された37例を対象とし、術後経過観察中3力月以上経て尿失 禁の程度および満足度をアンケート形式で回答してもらい、また Pad test は国際尿禁制学会(ICS) の1時間法とLeachらのnumerical pad scoring systemの2方法で施行し、尿失禁の量、Padの使用枚数と患 者の満足度の相関を検討した。【結果】全例から有効な回答が得

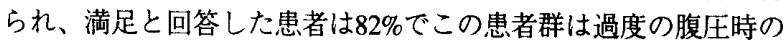
々尿失禁が生じ、Padの1日使用枚数は平均0.3枚、1時間量は平均 $5.8 \mathrm{ml}$ であり、不満足と回答した患者は $18 \%$ でこの患者群は就寝時 でも尿失禁が生じ、Padの1日使用枚数は平均3.7枚、1時間量は平 均93mlであった。またPadの1日使用枚数と1時間量に相関は認めら れなかった。【総括】前立腺全摘術後の術後尿失禁は患者のQOL を損ねる重要な問題であるがその評価は尿失禁の定義や測定方 法、判定する時期により異なり、また患者の訴える実際の重症度 之医師の施行する評価での重症度に差異があり、今後前立腺全摘 術後の術後尿失禁に対しての統一された評価が必要である。 前立腺全摘術 尿失禁 Pad test
\end{abstract}

\title{
P-535 前立腺全摘後の尿失禁と性機能障害
}

\section{合敷中央病院 泌尿器科1）}

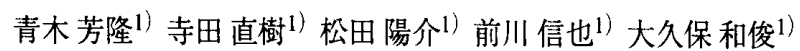
小倉啓司1）荒井陽一1)

【目的】前立腺癌に対寸る前立腺全摘術の排尿之性機能への影響 を、アンケートを用いて前向きに検討した。対象と方法】1994年 から1998年に倉敷中央病院で前立腺全摘術を受けた前立腺癌患者 で術後 1 年以上経過した 47 症例である。平均年齢66.9歳(52-80葴)。 両側または片側神経温存は37例（79\%）に施行。尿失禁について は内外の文献を参考に独自の調查票を作成し、性機能については 札㹸医大式性機能調查票を用いた。【結果】術後 1 年経過した時 点で、padの使用状況は、81\%が pad不要、17\%が1日 1 枚以内で

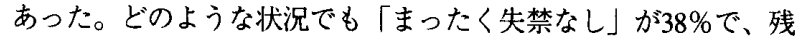
りの症例は高度の腹圧時に尿失禁を経験していた。尿失禁による 日常生活への影響では、94\%が「まったく支障なし」または「ほ とんど支障なし」と回答した。性機能調查に执いては、まったく 勃起不能と答えたのが術前 $16 \%$ であるのに対し、術後は60\%に増 加していた。性生活に対して満足していると答えたのは、術前

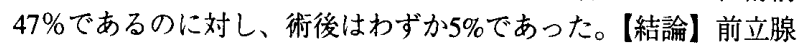
全摘術後に、日常生活で重大な支障をきたすような尿失禁は稀で あることがわかった。しかし性機能に対する影響はかなり梁刻で あり、術前に十分な説明が必要であることを再認識した。 前立腺全摘術 尿失禁 性機能
P-536 根治的前立腺接除術後のlymphocele formationについての検垨

\section{広島市民病院 泌尿器科1）広島市民病院 放射線科 2}

市川 孝治1）高尾 彰1）中山 恭樹1）三枝 道尚1）浅野 聰平1） 荒巻謙二1）辻修一2)

【目的】根治的前立腺摘除術後に認められるlymphoceleについて, 頻度，大きさを調べ臨床症状との関係を検討した。【対象と方法】 1997年12月から1999年11月の間に，前立腺癌にて䎵骨後式根治的 前立腺摘除術を受けた22例を対象とした。発熱，創縫合不全，ド レーン抜去時期及び抜去時の排液量, 浮腫などの臨床症状と lymphocele形成との関係を検討した。この内，1999年の11例に対し てはprospective studyとして, ドレーン拔去後6 12日目にCT検査を 施行し無症候性lymphoceleの有無も調べた。結果】22例中症候性 lymphocele として, 陰襄, 下肢浮腫5例 $(22.7 \%)$, 創縫合不全 1 例 (4.5\%), 発熱 2 例 $(9.1 \%)$ に認められ，この2例にはドレナージが必要 であった。1999年のprospective studyでのlymphocele形成率は36.4\%で あり，平均体積は $12.3 \mathrm{~cm}^{3}(2.0-34.9)$ であった。この間の症候性 lymphoceleは陰囊，下肢浮腫3例(27\%)のみであった。無症候性 lymphoceleを 1 例 $(9 \%)$ に認めた。ドレーン拔去時期，抜去時の排液 量とlymphocele形成との間には有意な関係はなかった。結論】恥 骨後式根治的前立腺摘除術では36.4\%にlymphoceleが認められた。 陰豪や下肢浮腫を認めた場合, lymphoceleの出現を考虑に入れた術 後管理を行うとともに，発熱が続けばlymphoceleへの感染を考えド レナージなどの処置を行うことが重要であると思われた。

lymphocele 前立腺癌 根治的前立腺摘除術 